\title{
DROPSHIPPING DALAM PERSPEKTIF KONSEP JUAL BELI ISLAM
}

\author{
Elpina Pitriani ${ }^{1}$ dan Deni Purnama ${ }^{2}$
}

${ }^{1}$ Marketing freelance di bukalapak.com, Depok, Jawa Barat. Email: elpinapitrian@ymail.com

2Program Studi Perbankan Syariah, Sekolah Tinggi Ekonomi Islam SEBI, Depok, Jawa Barat. Email: dpurnama5818@gmail.com

\begin{abstract}
ABSTRAK: Islam menghalalkan jual beli karena sangat diperlukan masyarakat. Namun demikian dalam pelaksanaannya diperlukan aturanaturan yang kokoh yang harus dipelihara untuk menjamin muamalah yang baik. Jual beli tidak sempurna jika tidak ada kepemilikan barang oleh pelaku akad. Semakin canggih dan berkembang teknologi informasi yang pesat dapat memacu pergeseran dalam dunia bisnis, menyebabkan muncul bisnis yang tidak mengharuskan penjual memiliki barang, yang disebut dengan dropshipping. Jenis penelitian ini menggunakan pendekatan studi literatur pustaka, menggunakan metode deskriptif kualitatif. Hasil penelitian ini menunjukkan : (1). Praktik jual beli dropshipping dari sisi pelaku akad (penjual pembeli) dan ijab qobul telah memenuhi rukun dan syarat jual beli Islam, dari sisi kepemilikan atas objek barang memiliki dua pendapat, yaitu: pertama, diperbolehkan dengan catatan penjual mendapatkan ijin dari pemilik barang dan penjual dapat mengadakan atau menghadirkan barang tersebut. Kedua dilarang, karena penjual menjual barang bukan miliknya/ barang masih berada pada pemiliknya (supplier). (2). Dalam proses dropshipping, penjual dilarang melakukan penipuan atau kecurangan, penjual tidak boleh memberikan penjelasan yang tidak jelas tentang barang dan harga kepada konsumen dan melepas keluhan dari konsumen.
\end{abstract}

\section{Kata Kunci: Jual beli, Dropshipping, Akad, dan Harga}

ABSTRACT: Islam has allowed trading because it's very needed by the society. However, in its implementation required the substantial rules stout that should be maintained to ensure the good transaction. Trading is not perfect but having any goods by the seller. Increasingly advanced and developmental the information technology a rapid progress encourage a movement in the business world, causing the emergence of business that is not requires the seller possess items that is dropshipping. The research use the library study, using qualitative descriptive method. The results showed that: (1). Dropshipping from the side of the seller and buyer and ijab qobul have met cornerstone and the conditions of buying and selling of islam, and from the side of possession of an object goods having two: first, it is allowed, with note seller get permission from the owner of goods and seller can convene or presenting these goods. Second, forbidden, because the seller sells goods instead of possession and still to the owners (supplier). (2). In the process the seller is prohibited from conducting fraud or cheating, can not give the unclear explanation about the goods and the price to consumers and release complaint from customer.

Keywords: Trade, Dropshiping, Contract, and Price 


\section{PENDAHULUAN}

Jual beli yang dilaksanakan oleh masyarakat sekarang semakin berkembang dari jual beli yang dilaksanakan pada zaman dahulu, dikarenakan banyak faktor yang mempengaruhinya. Salah satunya adalah perkembangan teknologi internet yang sangat mempengaruhi fungsi teknologi sesuai manfaat yang dibutuhkan oleh pengguna internet. Internet merupakan salah satu media yang dapat membantu manusia melakukan interaksi, berkomunikasi bahkan media untuk berniaga dengan berbagai orang dari berbagai dunia dengan cepat dan murah.

Perkembangan teknologi internet yang sangat pesat pada saat ini mempengaruhi hampir seluruh aspek kehidupan manusia. Teknologi Informasi yang disertai perkembangan internet saling mendukung satu sama lain sehingga melahirkan konsep Teknologi Informasi berbasis internet yang perkembangannya semakin luas dan semakin banyak diterapkan dalam bisnis perusahaan di berbagai bidang demi tercapainya tujuan yang diinginkan oleh perusahaan (Mahmudi , 2013, hlm.1).

Menurut data dari http://apjii.or.id tahun 2013 yang jumlahnya 82 juta pengguna internet atau 30\% dari total penduduk Indonesia akan meningkat pada tahun 2014 menjadi 107 juta pengguna dan Asosiasi Penyelenggara Jasa Internet Indonesia (APJII) memproyeksikan pada tahun 2015 menjadi 139 juta pengguna atau 50\% dari penduduk Indonesia. Peningkatan penggunaan tersebut di dukung oleh tingkat pertumbuhan masyarakat Indonesia yang sangat tinggi dan peningkatan itu akan terjadi seiring transformasi dan perkembangan teknologi 4G, termasuk Wimax, Fiber to the Home (FTTH), dan spektrum tambahan 3G untuk operator.Peluang bisnis semakin terbuka lebar karena semakin dibutuhkannya akses internet, lokalisasi konten, aplikasi, $e$ commerce, dan data center.

Teknologi internet sudah terbukti merupakan salah satu media informasi yang efektif dan efisien dalam penyebaran informasi yang dapat diakses oleh siapa saja, kapan saja dan dimana saja. Hal ini telah menggeser dunia bisnis offline dengan perkembangan teknologi internet yang mempunyai efek yang sangat besar pada perdagangan atau bisnis, dengan memberikan kenyamanan pada konsumen dalam transaksi yang dibangun melalui dunia maya yang disebut online shop atau e-commerce, karena lebih mudah mendapatkan barang diinginkan dan dapat memperluas jangkauan target pasar. Hanya dari rumah atau ruang kantor, calon pembeli dapat melihat produk-produk pada layar komputer, mengakses informasinya, memesan dan membayar dengan pilihan yang tersedia.

Data dari lembaga riset $\underline{I C D}$ memprediksi bahwa pasar e-commerce di Indonesia akan tumbuh 42\% dari tahun 2012 hingga 2015. Angka ini lebih tinggi jika dibandingkan negara lain seperti Malaysia (14\%), Thailand (22\%), dan Filipina (28\%) (http://startupbisnis.com). Diprediksikan penjualan online di Indonesia akan selalu meningkat tiap tahunnya.

Dalam bisnis online yang menjadi salah satu kendala utama bagi pebisnis online adalah menyediakan barang yang harus dijual. Stok barang jelas membutuhkan modal, yang kadang menjadi masalah besar bagi pebisnis dengan modal kecil. Penyediaan stok barang juga membuat keuntungan pedagang online menjadi lebih kecil, karena mereka harus membayar biaya kirim dari supplier ke rumah mereka, sebelum dikirim lagi kepada 
pembeli. Pada saat ini muncul salah satu model bisnis online internet marketing dengan istilah dropshipping.

Dropshipping adalah suatu usaha penjualan produk tanpa harus memiliki produk apapun (Iswidharmanjaya, 2012, hlm 5). Dengan kata lain Dropshipping adalah penjualan produk yang memungkinkan penjual menjualkan produknya kepada pelangggan, penjual dalam hal ini menjual barang ke pelanggan dengan bermodalkan gambar dari pemiliki (supplier) (tanpa harus menyetok barang) dan menjual ke pelanggan dengan harga yang ditentukan. Jadi, penjual adalah pelaku aktif untuk mencari pelanggan,

Pada sistem dropshipping ini proses pemasaran bisa dilakukan secara online maupun offline, tetapi biasanya cara online lebih efektif bagi sebagian besar orang. Mereka tidak harus memiliki barang. Cukup menggunakan beberapa sarana atau media yang dimiliki oleh penjual untuk memasarkan produk secara online, yaitu melalui forum, toko online, blog pribadi, media sosial (Facebook, Twitter, Instagram), lewat aplikasi messenger smartphone (BBM, Whatsapp, Line, wechat), dan media lainnya, lalu jika ada pesanan, mereka tinggal menghubungi pihak supplier atau grosir. Setelah itu pihak supplier atau grosir yang mengirimkan barang langsung kepada pembeli dengan nama pengirim yaitu penjual.

Sistem jual beli dropship pada toko online mengalami peningkatan dengan dipicu oleh jumlah pengguna internet dan handpone pintar, mengingat pengguna internet dinegeri ini terus meningkat dan memberikan peluang usaha untuk menjadikan sebagai bisnis sampingan tanpa menganggu aktifitas lainnya.

Tabel 1. 1 Perkembangan Jual Beli Dropshipping

\begin{tabular}{|c|c|}
\hline Tahun & Jual Beli Dropshipping \\
\hline 2011 & 22 \\
\hline 2012 & 138 \\
\hline 2013 & 304 \\
\hline 2014 & 471 \\
\hline $2015 /$ juni & 611 \\
\hline
\end{tabular}

Sumber : http://www.indonetwork.co.id,

Dari tabel diatas, dapat diambil kesimpulan bahwa jual beli yang menerapkan sistem dropshipping terus meningkat dan ini menjadi sebuah peluang usaha, bahkan pada tahun 2014 sudah mencapai 471 toko yang menggunakan sistem dropshipping dan diperkirakan akan lebih meningkat pada tahun 2015, dengan melihat angka perkembangan hingga pada bulan juni 2015 mencapai 611 toko per tanggal 3 juni 2015 .

Sistem jual beli dropshipping ini mendorong para peminat bisnis untuk melakukannya sebagai pekerjaan sampingan karena dalam memulai bisnis dengan sistem dropshipping ini tidak memerlukan modal awal atau modal kecil untuk melakukan pembelian barang, dengan demikian dapat meminimalkan jumlah modal, dan dapat meminimalisir resiko kerugian,dan menghemat waktu, Barang yang dibeli konsumen dikirim langsung oleh supplier sehingga Anda tak perlu menyiapkan gudang penyimpanan barang, sehingga menjadi salah satu alternatif pekerjaan sampingan yang mudah dan efektif (Komputer, 2013, hlm. 15). 
Jual beli sistem dropshipping dalam bisnis online merupakan sebuah bisnis menjanjikan dalam mendatangkan jutaan rupiah ke rekening pelaku bisnis, akan tetapi jual beli ini, nama baik menjadi taruhan, karena konsumen bisa melakukan over complain atas produk barang yang dijual tidak bersifat ready stock. Mengingat barang yang dijual tidak secara langsung penjual kirim sendiri, maka bisa saja saat konsumen atau pembeli melakukan komplain karena ada cacat atau kerusakan barang yang diterima pembeli, anda sebagai penjual akan mengalami kesulitan tersendiri dan nama baik sebagai penjual menjadi jelek dengan komplain tersebut ( Komputer, 2013, hlm. 16).

Jual beli model ini masih menjadi pro dan kontra di kalangan para ulama, akan hukum boleh dan tidaknya model jual beli dropshipping. Ada ulama yang menyatakan setuju dan tidak setuju jual beli dengan sistem dropshipping. Menurut Sarwat (2013) Sebagian mengatakan haram dengan berbagai dalil dan alasan dan sebagian mengatakan halal dengan berbagai syarat. Jual beli dropship ini tidak melanggar ketentuan syariah walaupun sebagai penjual belum memiliki barang, dan modal sebagai penjual hanya menawarkan, tetapi syariat Islam membolehkan akad seperti ini (Sarwat, 2013).

Menurut Arifin (2015, hlm. 6) prinsip syari'at dalam pemiagaan yaitu : Kejujuran, Jangan menjual barang yang tidak anda miliki, hindari riba dan berbagai celahnya. Sistem dropshipping, pada praktiknya, bisa melanggar ketiga atau salah satu prinsip tersebut sehingga keluar dari aturan syari'at alias haram. Menurut Khulwah (2013, hlm. 3-4) kepemilikian barang dalam jual beli menjadi hal yang mutlak harus terpenuhi, karena barang yang diperjual belikan harus termasuk dalam barang yang dimiliki secara penuh oleh penjual. Jika dalam transaksi jual beli barang tidak dimiliki secara penuh maka barang tersebut tidak dapat dijual. Tetapi bagaimana dengan jual beli dropshipping yang memberikan kemudahan menjual dengan tidak memiliki barang, yaitu dengan hanya memiliki gambar produknya barang yang dijual.

Jual beli sistem dropshipping menjadi menarik untuk diteliti melihat uraian diatas, bahwa kepemilikan barang yang akan dijual oleh penjual dan mempertimbangkan kemashlahatan dan kemudharatan akan transaksi ini. Model jual beli dropshipping ini dapat dicurigai bahwa tidak memenuhi syarat dan rukun jual beli sesuai syariah, Maka penulis tertarik untuk mengkaji tentang rukun dan syarat dropshipping sesuai syariah dengan judul "DROPSHIPPING DALAM PERSPEKTIF KONSEP JUAL BELI ISLAM"

\section{TELAAH PUSTAKA}

\section{Jual Beli}

Jual beli dalam istilah bahasa arab disebut dengan kata al-bai' yang berarti menjual, mengganti dan menukar sesuatu dengan sesuatu yang lain (Hasan, 2003, hlm.113).Secara termonologi Jual beli yang dikemukakan ulama Hanafiyah, jual beli adalah saling tukar menukar harta melalui cara tertentu. Cara yang khusus yang dimaksud ulama Hanafiyah adalah melalui ijab dan qabul, sesuai harta yang perjual belikan harus bermanfaat bagi manusia. Menurut ulama Malikiyah, Syafi'iyah dan Hanabilah, jual beli adalah saling menukar harta dengan harta dalam bentuk pemindahan milik dan pemilikan (Haroen, 2000, hlm.111-112).

Secara syar'i jual beli adalah pertukaran harta dengan harta, atau pemindahan kepemilikan dengan kompensasi menurut konteks yang disyariatkan. Jual beli 
disyariatkan oleh Allah untuk hamba-hambanya sebagai kelapangan dan kemudahan (AsSabatin, 2009, hlm. 107).

Imam Nawawi dalam kitab majmu' mengatakan jual beli tukar menukar barang dengan barang dengan bermaksud memberikan kepemilikan. Ibnu Qudamah dalam kitab al-mugni mendefinisikan jual beli dengan tukar menukar barang yang bertujuan memberikan kepemilikan dan menerima hak milik (Az- Zuhaili, 2011, hlm.25).

Menurut Sabiq (2004, hlm. 120), Jual beli adalah pertukaran harta tertentu dengan harta lain berdasarkan keridhaan antara keduanya. Atau memindahkan hak milik dengan hak lain berdasarkan persetujuan dan hitungan materi.

Dari pengertian diatas dapat disimpulkan bahwa jual beli merupakan pertukaran antara harta yang dimiliki dengan harta lain dengan menggunakan cara-cara yang dibolehkan dan memberikan manfaat, dan didasari dengan kerelaan antara kedua belah pihak.

\section{Dasar Hukum}

Jual beli merupakan akad yang dibolehkan berdasarkan Al-Qur'an, Sunnah, dan Ijma' ulama. Dilihat dari aspek hukum jual beli hukumnya mubah kecuali jual beli yang dilarang oleh syara', adapun dasar hukum dari Al-Qur'an antara lain :

Artinya: "Dan Allah menghalalkan jual beli dan mengharamkan riba."(QS.Al-baqarah [2]: 275)

Artinya: "Dan persaksikanlah apabila kamu berjual beli; dan janganlah penulis dan saksi memudharatkan yang bermuamalah (dan jangan juga yang bermuamalah memudharatkan para saksi dan penulis). Jika kamu lakukan (yang demikian), maka sesungguhnya hal itu adalah suatu kefasikan pada diri kamu. Dan bertakwalah kepada Allah; Allah mengajarmu; dan Allah Maha mengetahui segala sesuatu."(QS.Albaqarah [2]:282)

Sedangkan, dasar hukum dari sunnah antara lain :

Artinya; Nabi menjawab : usaha seorang dengan tangannya sendiri dan setiap jual beli yang mabru." (diriwayatkan oleh Al-Bazzar dan dishahihkan oleh Al-Hakim).

Artinya : "Dari Hakim bin Hizam dari Nabi saw. beliau bersabda:"Orang yang bertransaksi jual beli berhak khiyar (memilih) selama keduanya belum berpisah "(HR. al-Bukhari).

\section{Hukum Jual Beli}

Dari kandungan ayat-ayat Allah dan sabda-sabda Rasul diatas, para ulama fiqih mengatakan bahwa hukum asal dari jual beli adalah mubah (boleh). Akan tetapi, pada situasi-situasi tertentu, menurut imam Asy-Syaitibi (790 H), pakar fiqh Maliki, hukumnya boleh berubah menjadi wajib. Imam Asy-Syaitibi mencontohkan dengan praktik ihtikar (penimbunan barang sehingga persediaan barang hilang dari pasar dan harga melonjak naik). Apabila terjadi praktek semacam itu, maka pemerintah boleh memaksa para pedagang menjual barang-barang sesuai dengan harga pasar sebelum terjadi pelonjakan harga barang itu. Para pedagang wajib memenuhi ketentuan pemerintah di dalam menentukan harga pasaran (Hasan, 2003, hlm.117).

\section{Rukun Jual Beli}

Jual beli merupakan suatu perbuatan hukum yang mempunyai konsekuensi terjadinya peralihan hak atas sesuatu barang dari pihak penjual kepada pembeli, maka dengan sendirinya dalam perbuatan hukum ini haruslah dipenuhi rukun dan syarat sahnya jual beli. Menurut jumhur ulama rukun jual beli mencakup empat, antara lain : (Az-zuhaili, 2011, hlm 29). 
1. Penjual, ia harus memiliki barang yang dijualnya atau mendapatkan izin untuk dijualnya, dan sehat akalnya.

2. Pembeli, disyaratkan diperbolehkan bertindak dalam arti ia bukan orang yang kurang waras, atau bukan anak kecil yang tidak mempunyai izin untuk membeli.

3. Barang yang dijual, barang yang dijual harus merupakan yang hal yang diperbolehkan dijual, bersih, bisa diserahkan kepada pembeli, dan bisa diketahui pembeli meskipin hanya dengan ciri-ciri.

4. Pernyataan kata ,yaitu ijab (penyerahan) dan Qabul (penerimaan) dengan perkataan, misalnya pembeli berkata, "juallah barang ini kepadaku."Atau ijab dan Qabul dengan perbuatan, dan pembeli berkata, "juallah pakaian ini kepadamu,"kemudian penjual memberikan pakaian yang dimaksud kepada pembeli.

\section{Syarat-Syarat Jual Beli}

Transaksi jual-beli baru dinyatakan sah apabila terpenuhi syarat jual beli sesuai dengan rukun jual beli,yaitu (Muslisch, 2010, hlm.187-188):

1. Syarat pelaku akad

Para Ulama fiqih sepakat menyatakan bahwa orang yang melakukan aqad jual beli harus memenuhi syarat:

a) Berakal yakni mumayyiz, agar dia tidak terkicuh, orang yang gila atau bodoh dan anak kecil tidak sah jual belinya. Adapun yang dimaksud berakal, yaitu dapat membedakan atau memilih mana yang terbaik bagi dirinya, dan apabila salah satu pihak tidak berakal maka jual beli yang diadakan tidak sah.

b) Hendaknya pelaku transaksi tidak sendirian,dengan demikian akad yang dilakukan satu orang yang mewakili dua pihak hukumnya tidak sah, kecuali jika wakil itu adalah ayah.

c) Atas kehendak sendiri.

Niat penuh kerelaan yang ada bagi setiap pihak untuk melepaskan hak miliknya dan memperoleh ganti hak milik orang lain harus diciptakan dalam kondisi suka sama suka. Maksudnya adalah bahwa dalam melakukan perbuatan jual beli tersebut salah satu pihak tidak melakukan suatu tekanan atau paksaan terhadap pihak lainnya, sehingga apabila terjadi transaksi jual beli bukan atas kehendak sendiri tetapi dengan adanya paksaan, maka transaksi jual beli tersebut tidak sah ( Djamil, 1992, hlm.141-142).

2. Syarat barang yang menjadi objek akad

Yang dimaksud dengan obyek jual beli di sini adalah benda yang menjadi sebab terjadinya perjanjian jual beli. Syarat-syarat barang akad adalah sebagai berikut (Sabiq, 2004, hlm.123).

a. Suci(Halal dan Baik)

Tidak sah menjual najis atau barang haram seperti darah, bangkai dan daging babi. Karena benda-benda tersebut menurut syariat tidak dapat digunakan. Ini didasarkan atas hadits Rasulullah "Sesungguhnya Allah mengharamkan jual beli khamar, bangkai, babi, dan patung-patung". Mengambil manfaat dari lemak bangkai, bukan untuk diperjualbelikan hukumnya boleh. Contoh memberi minyak pada kulit, dijadikan bahan bakar penerangan. 
Ibnu Qayyim berpendapat atas hadits tersebut bahwa semua perbuatan tersebut adalah haram, dan menjualbelikannya, sekalipun pembeli menggunakannya untuk kepentingan yang sama. Mayoritas ulama berpendapat bahwa semua jenis barang najis berlaku ketentuan haram. Hanafi dan Zhahiri mengecualikan barang yang mempunyai manfaat dan halal untuk diperjualbelikan.

b. Bermanfaat

Maksudnya adalah barang yang tidak bermanfaat tidak sah untuk diperjual belikan. Oleh sebab itu, bangkai, khamar dan darah, tidak sah menjadi objek jual beli, karena dalam pandangan syara' benda-benda seperti itu tidak bermanfaat bagi muslim. Pemanfaatannya itu bisa dilakukan dalam bentuk minum, makan, bermain, menjual, membeli dan lain-lainnya (As-Sabatin, 2009, hlm. 132).

c. Milik orang yang melakukan akad

Maksudnya adalah bahwa orang yang melakukan transaksi jual beli atas suatu barang adalah pemilik sah dari barang tersebut atau orang yang telah mendapat izin dari pemilik sah barang. Tidak sah menjual barang yang belum menjadi hak milik. dan tidak sah menjual barang yang tidak ada atau diluar kemampuan penjual untuk menyerahkannya (Karim, 2004, hlm 92).

d. Mampu diserahkan oleh pelaku akad

Boleh diserah terima saat akad berlangsung, atau pada waktu yang disepakati bersama ketika transaksi berlangsung. Sesuatu yang tidak dapat dapat diserahkan secara konkrit maka tidak sah hukumnya, seperti ikan dalam air, burung yang terbang.

e. Mengetahui status barang (kualitas, kuantitas, jenis dan lain-lain)

Maksud keberadaan barang diketahui oleh penjual dan pembeli, yaitu mengenai bentuk, takaran, sifat dan kualitas barang. Apabila dalam suatu transaksi keadaan barang dan jumlah harganya tidak diketahui, maka perjanjian jual beli tersebut tidak sah karena perjanjian tersebut mengandung unsur penipuan (gharar).

2. Syarat akad (Ijab dan Qabul)

Syarat akad yang sangat penting adalah bahwa qabul harus sesuai dengan ijab, dalam arti pembeli menerima apa yang diijabkan (dinyatakan) oleh penjual. Tiga hal yang menjadi syarat dalam ijab dan qabul (Az-Zuhaili, 2011, hlm. 37-41) :

a. Legalitas pelaku transaksi

b. Hendaknya pernyataan qabul sesuai dengan kandungan pernyataan ijab

c. Transaksi dilakukan satu tempat.

Para ulama fiqih sepakat menyatakan bahwa unsur utama dari jual beli adalah kerelaan kedua belah pihak. Apabila ijab qabul telah diucapkan dalam akad jual beli, maka pemilikan barang atau uang telah berpindah tangan dari pemilik semula.

\section{Dropshipping}

Dropshipping adalah metode berdagang, bisa dilakukan oleh badan usaha atau perorangan (retail atau pengeceran) tidak melakukan penyetokan barang dari jalinan kerja sama dengan perusahaan lain yang memiliki barang sesungguhnya(supplier) (Sulianti, 2013, hlm. 2). Menurut Iswidharmanjaya (2012, hlm. 5) Dropshipping adalah suatu usaha penjualan produk tanpa harus memiliki produk apapun. Ada 3 pihak yang terlibat dalam transaksi di atas, Dropsipper, Penjual, dan Pembeli. Ada satu istilah yang 
perlu diluruskan terkait siapakah dropshipper. lebih tepat, dropshipper bukanlah pelaku bisnis online yang menawarkan barang ke konsumen. Beberapa situs berbahasa Inggris yang mengupas tentang dropshipping menegaskan bahwa dropshipper adalah pemilik barang, baik dia produsen, toko, atau agen. Sedangkan pihak yang menawarkan barang itu penjual.

Sistem dropship memungkinkan anda berjualan tanpa harus repot menyediakan stok barang dan melakukan pengiriman. Posisi anda sebenarnya sebagai marketing. Yang bertugas mencari pembeli, kemudian distributor melakukan pengiriman kepembeli atas nama anda(penjual). Tentu saja dengan melakukan transfer terlebih dahulu sesuai dengan harga yang disepakati (Setiawan, 2014, hlm, 96).

\section{Mekanisme Transaksi Dropshipping}

Proses jual beli dengan sistem dropshipping pertama-tama pembeli memesan barang dan membayarkan sejumlah uang pada penjual. Lalu penjual memberikan informasi bahwa pemesanan pada dropshipper, penjual pun membayarkan uang pada dropshipper atas harga yang sudah dikurangi laba dari penjual. Selanjutnya tinggal tugas dropshipper yakni mengirimkan produk pesanan pembeli dengan mencantumkan alamat penjual (Iswidharmanjaya, 2012, hlm 7).

\section{Gambar 2. 1 Skema Bisnis Dropshipping}

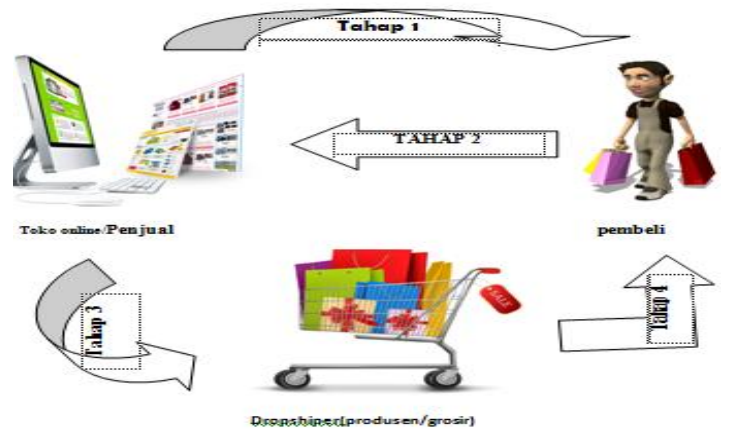

Keterangan :

1. Penjual mempromosikan produk di situs, blog pribadi, toko online, lewat smartphone (line, BBM, WhatsApp,Instagram) dan lain-lain

2. Pembeli tertarik dengan produk yang dipromosikan dan memesan produk yang diinginkan. Maka mereka harus mengirimkan sejumlah uang ke rekening penjual.

3. Selanjutnya setelah uang diterima maka saatnya penjual menginformasikan kepada pihak dropshipper/produsen atau grosir untuk dikirimkan produk langsung ke pembeli (konsumen) anda atas nama penjual(anda) atau toko penjual. Dan mengirim uang ke supplier yang sudah diambil labanya.

4. Pastikan perusahaan dropshipper mengirimkan produk pesanan pembeli ke alamat pembeli. Pada kemasan kiriman barang yang tercantum adalah alamat dan nama toko anda (penjual). Jadi pembeli tidak pernah tahu bahwa barang yang dibeli adalah milik dropshipper.

\section{Kelebihan Dan Kekurangan Dropshipping}

a) Kelebihan Dropshipping (Purnomo, 2012, hlm.4). 
Jika dibanding dengan bisnis-bisnis yang lain, ada banyak keuntungan atau kelebihan dari bisnis dropshipping, diantaranya

1. Tidak perlu membeli produk terlebih dahulu, sehingga tidak membutuhkan modal yang besar. Jika sudah ada pembeli yang membayar, penjual tinggal meneruskan uang pembayaran tersebut kepada produsen/grosir(supplier) pada saat memesan produk untuk konsumen anda, setelah anda potong jumlahnya sebagai keuntungan anda tentunya.

2. Tidak perlu menyediakan ruang dan tempat untuk menyimpan barang.

3. Tidak perlu khawatir barang tidak laku atau rusak karena terlalu lama tersimpan.

4. Tidak perlu repot membungkus atau mengkemas barang dan mengirimkan barang ke konsumen. Karena supplier yang melakukannya.

5. Biaya operasional sangat kecil, karena tidak perlu membayar karyawan, mengeluarkan biaya pengemasan atau transportasi dan lainnya. Yang diperlukan hanya biaya pulsa atau biaya akses internet.

6. Tidak perlu memikirkan pembuatan promosi produk, karena pihak penyedia dropshipping sudah menyediakan katalog atau photo produk-produknya untuk anda gunakan sebagai sarana promosi

7. Kerena urusan produksi, packing, dan pengiriman barang dilakukan oleh pihak produsen/grosir, maka bisnis ini tidak banyak menyita banyak waktu.

8. Tidak perlu menyewa toko karena bisnis ini bisa dilakukan dirumah.

9. Transaksi. Berhubungan mayoritas produsen/grosir ini memiliki toko online yang buka 24 jam, maka transaksi bisa dilakukan dimana saja dan kapan saja.

10. Potensi penghasilan yang cukup besar karena umunya persentase keuntungan kita yang menetukan sendiri.

11. Untuk memulainya tidak memerlukan persiapan yang rumit,seperti layaknya membuka toko sendiri.

b) Kekurangan Jual Beli Dropshipping

Adapun kekurangan dari sistem dropshipping antara lain sebagai berikut (Wahana Komputer, 2013, hlm. 20):

1. Margin laba yang diperoleh tidak terlalu besar.

2. Adanya resiko kalah bersaing dengan reseller.

3. Kesulitan memantau stok barang.

4. Kesulitan menjawab komplain dari konsumen.

Ciri khas dari bisnis dropshipping terletak pada pengiriman barang ke alamat kosumen. Jika toko online pada umumnya bertanggung jawab atas pengiriman barang ke alamat konsumen, maka dalam sistem dropshipping, produsen/supplier yang melakukan hal tersebut. Itu artinya anda (penjual) tidak mengurus pengiriman dari pengepakan hingga masuk ke jasa ekspedisi (Enterprise, 2015, hlm 159).

Ada dua model pendekatan untuk mengatur jasa ekspedisi ini. Kedua model itu adalah :

1. Jika mitra supplier berada di kota yang sama dimana anda(penjual) mengoperasikan toko online.

2. Jika mitra produsen berada di banyak kota yang berbeda. 


\section{ANALISA PRAKTIK DROPSHIPPING PRESPEKTIF JUAL BELI}

Secara umum segala bentuk muamalah dalam perspektif hukum Islam, hukumnya adalah mubah (boleh dilakukan) berdasarkan pada kaidah fiqh, yaitu: "Artinya: Pada dasarnya segala hukum dalam muamalah adalah boleh,kecuali ada dalil yang melarang." (Djazuli, 2007, hlm.10). Islam membolehkan seluruh umatnya untuk melakukan berbagai bentuk muamalah, dengan tujuan untuk kemaslahatan bersama, akan tetapi kebolehan tersebut dapat berubah menjadi sesuatu yang dilarang apabila terdapat alasan yang mendukungnya.

Demikian juga dalam hal jual beli yang merupakan salah satu dari bentuk muamalah. Pada prinsipnya jual beli merupakan bentuk usaha yang dibolehkan dalam Islam, dan telah diatur dalam Al-Qur'an dan Sunnah. Ada beberapa alasan yang dapat mengakibatkan jual beli menjadi terlarang, salah satunya adalah apabila dalam jual beli tersebut mengakibatkan kerugian pada salah satu pihak yang berakad. Kesepakatan dan kerelaan (adanya unsur suka sama suka) sangat ditekankan dalam setiap jual beli. Namun hanya dengan kesepakatan dan kerelaan yang bermula dari suka sama suka tidak menjamin suatu transaksi dapat dinyatakan sah dalam Islam (Asnawi, 2004, hlm. 86).

Sebagai suatu akad, jual beli mempunyai rukun dan syarat yang harus dipenuhi sehingga jual beli itu dapat dikatakan sah oleh syara'. Apabila salah satu dari rukun tersebut tidak terpenuhi maka jual beli tersebut dapat dikategorikan sebagai jual beli yang tidak sah. Berkaitan dengan jual beli pada sistem dropshipping, penulis akan menganalisis dari segi hukum Islam berdasarkan pemenuhan rukun dan syarat jual beli, yaitu:

\section{Pelaku Akad}

Aqid adalah pihak-pihak yang melakukan transaksi, dalam hal jual beli mereka adalah penjual dan pembeli. Ulama fiqih memberikan persyaratan atau kriteria yang harus dipenuhi oleh aqid, yakni ia harus memiliki ahliyah, wilayah dan iradah (Muslich, 2010, hlm.116). Sedangkan, Jual beli model dropshipping ini banyak dilakukan dengan cara online, yaitu tidak jelas antara pembeli atau penjualnya, bisa saja penjual dan pembeli adalah anak kecil karena transaksi akadnya berlangsung dengan tidak bertatap muka secara langsung. Sedangkan untuk pembayarannya yaitu dengan cara mentransfer uang direkening bank atas nama olshop (penjual) yang ditujukan. Jadi secara tidak langsung penjual maupun pembeli menjadi nasabah suatu bank. Persyaratan menjadi nasabah pada suatu bank yaitu harus memiliki kartu tanda penduduk (KTP). Pembuatan KTP dapat terjadi ketika seseorang sudah mencapai umur 17 tahun dan dikatakan dewasa.

Dalam jual beli sistem dropshipping, para pelaku yang berakad, mereka melakukan akad jual beli atas kehendaknya sendiri dan tidak ada paksaan dari orang lain. Begitu juga dengan para penjual dan pembelinya adalah telah baligh dan cakap hukum. Penjual dengan kehendakannya sendiri melakukan berbagai promosi melalui berbagai media sosial yang dilakukannya tanpa henti-hentinya dan tanpa paksaan dari orang lain. Menurut Sulianta (2014, hlm.100), dalam menginformasikan barang-barang yang ditambahkan ke etalase online dan barang tertentu memiliki dibeli karena manfaatnya besar bagi calon pembeli, tidak ada salahnya menandai mereka pada foto produk. Lakukan hal ini dengan bijaksana dengan membuat pernyataan "silakan un-tag jika keberatan dengan informasin produk ini". Pembeli yang melakukan pembelian terhadap 
barang adalah atas keinginan dari dirinya sendiri. Dari penjelasan diatas bahwa praktek jual beli yang menggunakan sistem dropshipping pada jual beli online ditinjau dari segi syarat aqidnya telah sesuai dengan aturan jual beli yang diterapkan syariat Islam..

\section{Barang yang dijual}

Barang yang dijual harus merupakan yang diperbolehkan untuk diperjualbelikan, suci, memberi manfaat menurut syara', tidak dibatasi waktunya, dapat diserahterimakan dengan cepat maupun lambat, milik sendiri, diketahui (dilihat) pembeli meskipun hanya dengan ciri-cirinya. Objek dalam bisnis online harus memenuhi kriteria yang disyaratkan, yaitu berupa jasa atau komoditi yang halal, mempunyai nilai dan manfaat, memiliki kejelasan baik bentuk, fungsi maupun keadaannya, serta dapat diserah terimakan pada waktu, tempat(media) yang disepakati (Purkon, 2014, hlm. 31-32).

Ibnu Qayyim berkata “orang yang menjual sesuatu yang bukan miliknya termasuk jenis jual beli gharar, yang kadang bisa terjadi dan tidak. Ini juga mengandung unsur judi dan taruhan ( Muhammad Dawabah, 2005, hlm.107). Seorang penjual harus memiliki barang yang dijualnya atau mendapat izin untuk menjualnya. Dalam jual beli sistem jual beli dropshipping bahwa pihak yang melakukan transaksi jual beli, yaitu para penjual berjualan tanpa harus repot menyediakan stok barang (Setiawan, 2014, hlm.96). Dalam sistem ini seorang penjual tidak benar-benar memiliki barang, tidak mengetahui secara fisik produk yang ditawarkan ke konsumen karena barangnya masih di supplier.

Menurut Nur Baits dan Arifin (www.PengusahaMuslim.com, 2013), dan Afifuddin (Majalah asy-syariah, 2015) menyatakan terdapat larangan menjual barang yang tidak dia miliki dan sesuatu yang belum menjadi miliknya, sebagaimana sabda Rasulullah :

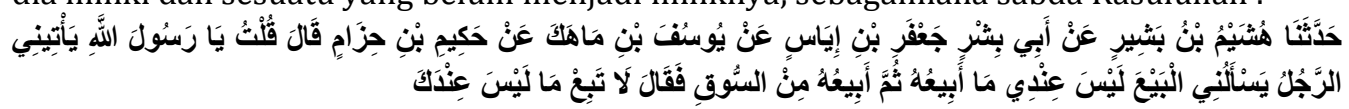

Artinya : "Dari Hakim bin Hizam, "Beliau berkata kepada Rasulullah, 'Wahai Rasulullah, ada orang yang mendatangiku. Orang tersebut ingin mengadakan transaksi jual beli, denganku, barang yang belum aku miliki. Bolehkah aku membelikan barang tertentu yang dia inginkan di pasar setelah bertransaksi dengan orang tersebut?' Kemudian, Nabi bersabda, 'Janganlah kau menjual barang yang belum kau miliki." (HR. Abu Daud, no. 3505; dinilai sahih oleh Al-Albani)

Dari hadist diatas menunjukkan adanya larangan yang tegas, bahwa seseorang tidak boleh menjual sesuatu kecuali telah dimiliki sebelum akad, baik dijual cash ataupun tempo. Dropshipping termasuk sistem jual beli yang tercakup dalam larangan hadis di atas, karena penjual sama sekali tidak memiliki barang yang ada di supplier. Namun, dalam kondisi yang sama, penjual menjual barang milik supplier. Ini artinya, penjual menjual barang yang bukan miliknya.

Tetapi jika yang memiliki barang minta untuk dijualkan, tentu saja hukumnya halal. Penjual berhak untuk mendapatkan fee atas jasa menjualkan. Dropshipping tidak dilarang asalkan tidak termasuk bai' muashalah dan bai' ma'dum yang dilarang. Adapun skim dropship yang diperbolehkan bisa dikatagorikan dalam beberapa skim transaksi : 1 . Penjual hanya sebagai marketing, dan dia mendapat fee, 2. Penjual menentukan harga sendiri, namun setelah mendapatkan pesanan barang, kemudian penjual membeli barang 
dari supplier, 3.Pembeli mengirimkan uang tunai kepada penjual sebesar harga barang yang akan dipesan dan membayar ongkos kirim barang (Kurniawan, 2012).

Penulis mengambil kesimpulan bahwa praktik jual beli dropshipping terdapat dua pendapat menurut para ulama diatas dari sisi kepemilikan barang, yaitu diperbolehkan, jika penjual dapat mengadakan barang atau menghadirkan barang yang dijual, dan penjual barang mendapatkan izin dari yang pemilik barang tersebut. Dropshipping dilarang karena barang itu belum milik sepenuhnya si penjual dan barang itu masih di tangan orang lain (supplier) tetapi barang itu dijual lagi pada pembeli. Penjual termasuk ahli yang sempurna, tetapi tidak memiliki al-wilayah, akad tersebut dipandang al-fudhul (didiamkan dan tidak memiliki hak) karena penjual menjual barang milik orang lain dan tidak mendapat izin untuk menjualnya.

Pada online shop terutama model dropshipping, barang akan tiba di alamat pembeli dalam waktu 2 atau 3 hari dan paling lambat 7 hari (1 minggu) dan dapat disesuaikan dengan penggunaan jasa yang ada pada alamat pembeli. Di dalam salah satu syarat barang yang di akadkan adalah mampu menyerahkan, Islam mengatakan bahwa yang dimaksud mampu menyerahkan yaitu pihak penjual (baik sebagai pemilik maupun sebagai kuasa) dapat menyerahkan barang yang diperjanjikan pada waktu penyerahan barang kepada pihak pembeli. Pembeli dapat mengetahui jangka waktu pengirimannya melalui informasi dalam biaya pengiriman,

Barang yang dipesan harus dijelaskan secara spesifikasi, baik kualitas maupun kuantitas. Misalnya jenis, macam, warna, ukuran, dan spesifikasi lain. maksudnya, setiap kriteria yang diinginkan harus ditetapkan dan dipahami oleh kedua belah pihak, seolaholah barang yang dimaksud berada diantara kedua belah pihak. Dengan demikian, ketika penyerahan barang itu dijamin 100\% tidak terjadi komplain dari kedua belah pihak (Sarwat, 2013).

Tempat penyerahan adalah sesuatu yang telah disepakati sebelumnya. Ketika tempat penyerahan barang berubah dari tempat yang telah disepakati tanpa adanya kesepakatan terlebih dahulu, maka salah satu atau kedua belah pihak berhak untuk membatalkan akad. Tetapi ketika keduanya tidak menyebutkan tempat, maka akad tetap sah menurut mayoritas ulama. Dalam praktek dropshipping tempat penyerahan barang yaitu barang diantarkan ke rumah konsumen melalui jasa pengiriman Seperti Jasa Pengiriman PT. Jalur Nugraha Ekakurir (JNE), PT. Citra Van Titipan Kilat (TIKI), PT. Post Indonesia dan lain-lain. Meskipun dalam transaksi ini tempat penyerahannya tidak disebutkan, tetapi transaksi ini tetap sah.

Unsur terpenting dalam jual beli adalah adanya kerelaan dari kedua belah pihak (aqid). Kerelaan tersebut bisa dilihat dari ijab dan qabul yang dilangsungkan. Pernyataan ijab dan qabul dapat dilakukan dengan lisan, tulisan/surat-menyurat, atau syarat yang memberi pengertian dengan jelas tentang adanya ijab dan qabul, dapat juga berupa perbuatan yang telah menjadi kebiasaan dalam ijab dan qobul (Asnawi, 2004, hlm. 78). Dalam hal ini akad yang dilakukan dalam sistem dropshipping adalah sesuai dengan cara akad yang kedua, yaitu dengan tulisan.

\section{Analisa Hal-Hal yang dilarang dalam Proses Dropshipping}

Fenomena internet telah membuka peluang pengembangan sistem transaksi bisnis elektronik dalam bentuk yang lebih inovatif (modern). Pada dasarnya jual beli online menggunakan internet sebagai alat, media, sarana, yang mana dalam kaidah syariah 
bersifat fleksibel dan dinamis. Hal ini termasuk persoalan teknis keduniawian, yang Rasulullah pasrahkan sepenuhnya selama dalam bidang muamalah kepada umat Islam untuk menguasai dan memanfaatkannya demi kemakmuran bersama (Huda, 2010, hlm. 75). Dalam hadis Rasulullah, disebutkan sebagai berikut:

Artinya: "Dari Abdullah bin mas'ud, dia berkata: "Apa yang dipandang baik menurut orang islam baik menurut Allah, dan apa yang dipandang jelek menurut orang islam maka jelek menurut Allah".

Sistem jual beli dropshipping dilarang apabila dalam sistem jual beli ini terjadi penipuan dan dalam transaksi pemesanan barang yang dipesan oleh pembeli tidak sesuai dengan barang yang telah diterima oleh pembeli dan penjual melepas klaim atas konsumen. Dalam sub bab ini penulis akan menjabarkan beberapa yang dilarang dalam proses dropshipping menurut Islam, dalam transaksi jual beli model dropshipping yang harus dihindari yaitu penipuan, ketidakjelasan barang dan harga dan melepas klaim konsumen. Sistem dropshipping pada praktiknya bisa melanggar prinsip tersebut, sehingga keluar dari aturan syariat.

Kejujuran merupakan kunci utama keberhasilan dan kelanggengan suatu bisnis (termasuk dalam promosi dan iklan). Promosi dan iklan yang mengandung kebohongan merupakan salah satu bentuk ketidakjujuran yang akan merugikan pebisnis dan produknya (Purkon, 2015, hlm. 15). Pada semua transaksi perniagaan, kejujuran sangat penting salah satu dalam perniagaan jual beli dropshipping, hal ini untuk menumbuhkan dan menjaga kepercayaan antara kedua belah pihak terutama para konsumen. Hal yang menjadi kekhawatiran penjual dan pembeli dalam model dropshipping, jika pembeli melakukan pembelian atau pemesanan, tidak melakukan pembayaran atau tidak melunasi sisa pembayarannya.

Penjualan online harus menampilkan secara utuh penampilan dan spesifikasi dari barang yang dijual. Oleh sebab itu dalam situs jual beli, penampilan dari suatu produk yang dijual dapat dilihat dari berbagai sisi. Begitu pula yang harus dilakukan pada penjualan online berbasis media sosial, penjual harus menampilkan fisik dari produk tersebut dari berbagai macam sisi. Bahkan jika perlu penjual perlu menampilkan video dari produk yang akan dijual tersebut, terutama cara menggunakan dari produk tersebut, sehingga calon pembeli dapat menilai kualitas dari barang yang ditawarkan tersebut. Tujuan dari penjual menampilkan gambar dari berbagai macam sisi ataupun video adalah untuk meminimalkan timbulnya permasalahan akibat perbedaan kualitas antara iklan yang ditampilkan dengan realitas barang yang dijual (Al-arif, 2013, hlm. 20).

Dalam syari'at perniagaan, Islam mengajarkan kita agar senantiasa membangun perniagaan di atas kejelasan. Kejelasan dalam harga, barang, dan akad. Sebagaimana Islam juga mensyari'atkan agar kita menjauhkan akad perniagaan yang kita jalin dari segala hal yang bersifat untung-untungan, atau yang disebut dalam bahasa arab dengan gharar, dikarenakan unsur gharar atau ketidakjelasan status, sangat rentan untuk menimbulkan persengketaan dan permusuhan (Badri, 2009). Kejelasan adalah salah satu hal yang terpenting dalam jual beli melalui internet, kejelasan ini harus ditunjukkan oleh kedua belah pihak (Haryosanne, 2013, hlm. 61)

Ketidakjelasan dalam barang yang dijual, baik jenisnya, kualitasnya, atau kadarnya dalam pandangan seorang pembeli, jual beli dalam sistem dropshipping dapat dilihat dari 
karakteristik gambar barang yang di perlihatkan diberbagai media pendukung dan untuk ukuran kualitas gambar produk sangat diperlukan bagi para konsumen. Dalam praktik dropshipping, objek barang kadang tidak sesuai dengan hasil pemotretan. Barang kadang terlihat lebih bagus dengan barang aslinya. Misalnya terjadi penyimpangan warna karena pengambilan gambar yang tidak tepat, skala yang tidak didefinisikan dengan nyata, bahkan layar monitor dapat menyajikan informasi warna yang salah, warna bisa menjadi lebih terang atau lebih redup. Jika terjadi seperti ini sebagai penjual sebaiknya dapat menjelaskan kepada pembeli dengan pernyataan bahwa barang yang diperdagangkan 85\%-90\% mirip dengan aslinya karena faktor teknis (Sulianta, 2014, hlm. 72).

Menurut Haryosanne (2013, hlm. 65) Ada beberapa batasan-batasan dalam melakukan aktivitas akad jual beli dan itu perlu adanya kejelasan dari objek yang akan diperjualbelikan. Kejelasan tersebut paling tidak harus memenuhi empat hal (dalam hal ini merupakan syarat barang yang diakadkan) antara lain:

1) Lawfulness, produk-produk yang di sediakan dalam jual beli dropshipping yaitu barang-barang tersebut halal untuk dipergunakan oleh manusia.

2) Mengenai existence, Toko online shop yang serius akan memberikan pelayan yang baik, mulai dari tampilan produk yang dipromosikan dengan menampikan ciriciri produk dengan rinci, mencantumkan alamat penjual yang jelas dan kontak yang dapat dihubungi, menyediakan kotak saran dan klaim konsumen dan terdapat tesnimoni dari konsumen sebelumnya.

3) Untuk masalah delivery, online shop selama ini dalam hal pengirimanya ada yang tidak tepat pada waktu yang dijanjikan. Sehingga pembeli komplain pada penjual Online shop tetapi ada sebagian penjual Online shop memberikan bukti bahwa penjual Online shop sudah mengirimnya, pembeli disuruh menunggu barang tersebut.

4) Mengenai price determination, dalam promosi penjual telah menampilkan semua gambar beserta keterangan produknya.

Pada kasus dropshipping, penjual bisa menentukan harga sesuai yang diinginkan, terlepas dari harga yang telah disepakati oleh penjual dan supplier/produsen. Harga atas barang biasanya di cantumkan langsung pada rincian gambar barang. Adanya ketentuan harga yang telah disepakati dengan uang dibayar dimuka terlebih dahulu sebelum menerima barang, tetap menggunakan keuntungan dari selisih harga aslinya. Dengan kejelasan atas harga jual beli model dropshipping ini agar tidak terjadi kekeliruan pada saat pembayaran.

Dalam pembayaran, pembeli dapat mengetahui berapa biaya yang harus dibayar dan jangka waktu pengirimannya, dapat diketahui dalam informasi biaya pengiriman, adapun besar kecilnya tergantung banyaknya suatu pesanan barang atau produk dan lokasi tujuan pengiriman. Biaya pengiriman akan menambahkan jumlah pembayaran tergantung banyaknya order dan jarak atau lokasi tujuan. Biaya pengiriman ditanggungkan pada pembeli. Penambahan biaya pengiriman ini diperbolehkan menurut hukum Islam, karena termasuk dalam unsur jual beli adalah adanya kerelaan baik dari pembeli maupun penjual.

Unsur kejelasan harus ada dalam jual beli sebagaimana hukum Islam yang disebutkan dalam hadits:

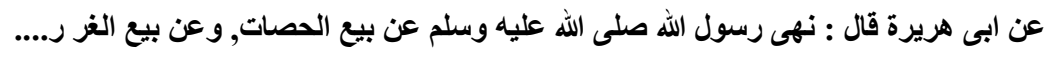


Artinya : "Bersumber dari Abu Hurairah, beliau berkata : Rasulullah SAW melarang jualbeli kerikil (bai'ul hashat) dan jual-beli yang sifatnya tidak jelas bai'ul gharar)”.

\section{Melepaskan keluhan konusmen}

Perdagangan yang terjadi antara penjual dan pembeli tidak sepenuhnya berjalan dengan lancar, terjadi kesalahpahaman sehingga menimbulkan bentuk protes atau komplain oleh pihak yang merasa dirugikan. Komplain terjadi bila pelanggan/konsumen tidak puas akan pelayanan atas barang yang dijualbelikan atau kesalahan yang telah dilakukan baik dari pihak supplier ataupun penjual itu sendiri maupun pihak lain yang terkait didalamnya yang mengakibatkan konsumen merasa dirugikan.

Memberikan kepuasan dan menjaga tingkat kepuasan pelanggan (pembeli/buyer) adalah hal nomor satu dalam bisnis penjualan dan harga mati bagi para pelaku usaha, termasuk dalam bisnis jual beli online model dropshipping. Banyak pelaku usaha rela memberikan fasilitas dan pelayanan maksimal untuk bisa menciptakan kepuasan bagi setiap konsumennya. Komplain paling banyak dilakukan oleh pembeli pada penjual. Beberapa hal yang mengakibatkan komplain dari pembeli antara lain: 1) Barang yang dikirim terlambat datang, 2) Barang yang diterima tidak sama dengan yang ada di dalam promosi, 3.) Terdapat kecacatan pada barang, 4) Pelayanan yang kurang memuaskan, 5) Tidak adanya penyelesaian dari pihak penjual.

Dalam transaksi dropshipping apabila pihak pembeli mempunyai keluhan terhadap barang yang dibeli akibat kelalaian atau kesalahan pihak penjual, pihak penjual telah menyediakan pelayanan (kotak saran atau kesan pembelian) konsumen dapat menghubungi penjual dengan cara membuka web diskusi atau menyampaikan keluhan dari para calon konsumen maupun konsumen. Sebagai seorang penjual maka harus peduli dengan masalah yang dihadapi oleh pelanggan/konsumen. Kepedulian ini ditunjukan dengan cara, misalnya rutin menjawab email atau pertanyaan dari pelanggan. Ketika pelanggan bertanya mengenai produk maka berikanlah penjelasan yang ramah dan tunjukan bahwa anda peduli (Helianthusonfri, 2013, hlm. 223).

Berdasarkan hasil penelitian, pada transaksi bisnis online hak-hak konsumen sangat riskan sekali untuk dilanggar, dalam hal ini konsumen tidak mendapatkan hakhaknya secara penuh dalam transaksi sistem dropshipping. Hak-hak tersebut antara lain :

1) Hak atas kenyamanan, keamanan dan keselamatan dalam mengkonsumsi barang dan/atau jasa. Hal ini dikarenakan para konsumen tidak langsung mengidentifikasi, melihat dan menyentuh barang yang akan dipesan.

2) Hak atas informasi yang benar, jelas dan jujur mengenai kondisi suatu barang. Hal ini dikarenakan pelaku usaha dan konsumen tidak bertemu secara langsung dan komunikasi terjadi jika konsumen tersebut aktif bertanya kepada pelaku usaha.

3) Hak untuk didengar pendapat dan keluhannya atas barang dan jasa yang digunakan. Karena penjual dan pembeli tidak bertemu secara langsung maka komunikasi terjadi melalui e-mail ataupu telephon dan atau toko online yang tidak mencantumkan alamat di dunia nyata dengan jelas sehingga sangat sulit konsumen dalam menyampaikan keluhan. 
Menurut penulis, hak konsumen untuk mendapatkan informasi yang jelas mengenai identitas perusahaan milik pelaku usaha dalam transaksi sangat diperlukan, seperti alamat jelas di dunia nyata dan nama pemilik toko online. Hak tersebut kurang dapat direalisasikan dalam transaksi online shop sistem dropshipping, karena pada website pelaku usaha sering kali tidak dicantumkan alamat lengkap perusahaan didunia nyata, biasanya yang ditampilkan pada website hanya nomor telephone dan alamt e-mail. Hal ini menurut penulis, sangat merugikan bagi konsumen jika dalam bertransaksi terjadi suatu permasalahan, seperti barang yang dikirim tidak sesuai dengan barang yang dipesan, barang yang dipesan belum sampai di tangan konsumen tepat pada waktunya. Sehingga konsumen akan kesulitan jika akan komplain pada pelaku usaha. Selain itu konsumen tidak mengetahui dengan jelas dengan siapa dia bertransaksi.

Penjual harus bisa menanggapi secepat dan sebaik mungkin klaim dari konsumen. Jangan sampai konsumen menunggu lama untuk mendapatkan jawaban dari penjual. Perlakukanlah konsumen tersebut layaknya konsumen sendiri. Meskipun hanya bertugas untuk menjualkan produk orang lain (Wulandari, 2014, hlm. 222). Pemilik bisnis online juga perlu memberikan layanan purna jual (after sales service) yang baik dan bertanggung jawab agar para pelanggan betah terus belanja pada toko online Anda. Agar bisa memuaskan pembeli yang telah membeli produk, pastikan kita tidak cuek dan mampu memberikan layanan purna jual yang baik (Serfiani, Purnomo, dan Hariyani, 2013, hlm. 305).

\section{SIMPULAN}

Transaksi model dropshipping setelah dikaji dari sisi rukun dan syarat jual beli Islam, telah memenuhi rukun akad dalam syariah. Sedangkan Pada sisi kepemilikan atas objek barang dalam praktik jual beli dropshipping memiliki dua pendapat, yaitu:

1) Dilarang, bahwa barang belum sepenuhnya milik penjual dikarenakan barangnya masih ditangan pemiliknya (supplier).

2) Diperbolehkan, meskipun penjual tidak memiliki stok barang yang akan dijual, dengan catatan penjual mendapatkan izin dari pemilik barang dan dapat mengadakan atau menghadirkan barang yang akan diperjualbelikan, karena penjual dalam transaksi model dropshipping prinsipnya adalah wakil bagi pemiliknya.

Hal-hal yang dilarang dalam proses dropshipping yang harus dihindari terutama bagi penjual yaitu: 1) Kecurangan atau penipuan yang dapat mengurangi kepercayaan calon konsumen atau pelanggan untuk melakukan pembelian secara online terutama model dropshipping. 2) Ketidakjelasan dalam barang dan harga, dalam sistem dropshipping kejelasan barang dan harga menjadi hal yang terpenting bagi konsumen untuk menghindari penjual online yang memiliki niat jahat dan kejelasan atas barang dan harga akan memberikan kenyamanan dalam melakukan transaksi.

Berdasarkan hal-hal yang telah penulis uraikan, untuk menganalisa lebih luas dengan menambah beberapa variabel dari variabel diatas, dan lakukanlah penelitian langsung pada pelaku dan konsumen yang melakukan transaksi dropshipping.

\section{DAFTAR PUSTAKA}

Al-Qur'an Tajwid dan terjemahannya. (2007). Departemen Agama RI. Yayasan PenyelenggaraanPenerjemahan/Penafsir Al-Qur'an (Revisi Terjemah Oleh Lajnah 
Pentashih Mushaf Al-Qur'an Depertemen Republik Indonesia). Bogor: PT Sygma Examedia Arkanleema.

Afifuddin, Muhammad. (2015). Jual Beli Dropship. Majalah Asy-syariah edisi-103.

Al-Arif, M. Nur Rianto. (2013). Penjualan On-Line Berbasis Media Sosial Dalam Perspektif Ekonomi Islam. Skripsi tidak dipublikasikan, Jakarta : UIN Syarif Hidayatullah.

Al-Mushlih, Abdullah \& Ash-Shawl, Shalah. (2004). Fikih Ekonomi Keuangan Islam. Jakarta : Darul Haq.

As-Sabatin, Yusuf. (2009). Bisnis Islami dan Kritik atas Praktik Bisnis Ala Kapitalis. Bogor: Al-Azhar Press.

Asyaraf, Muhammad Dawabah. (2005). Menjadi Pengusaha Muslim. Jakarta; Pustaka Alkautsar.

Asnawi, Haris Faulidi. (2004). Transaksi Bisnis E-commerce perspektif Islam. Yogyakarta: Magistra Insania press.

Ath-Thayyar, Abdullah bin Muhammad, dkk. (2009). Ensiklopedi Fiqih Muamalah dalam Pandangan 4 Mazhab. Yogyakarta : Maktabah al Hani.

Az-Zuhaili, Wahbah. (2011). Fiqih Islam Wa Adillatuhu, jilid IV \& V. Jakarta : Gema Insani.

Az-Zuhaili, Wahbah. (1989). Fiqih Al-Islam wa Adillatuh, Jilid IV. Beirut : Dar al-Fikr.

Badri, Muhammad Arifin. (2015). Jual beli sistem dropshipping. Majalah Furqon. No. 156 Ed. 9 Th ke-14.

Baits, Ammi Nur . (2013). Dropshipping dan Alternatif transaksi yang halal. http://pengusaha muslim.com. Diakses tanggal 21-April-2015.

Basyir, Achmad Azhar. (2009). Asas-Asas Hukum Muamalat. Yogyakarta : FAkultas Hukum UII.

Djamil, R.Abdul. (1992). Hukum Islam : Asas-asas Hukum Islam. Bandung: Mandar Maju.

Djuwaini, Dimyauddin. (2008).. Pengantar Fiqih Muamalah. Yogyakarta: Pustaka Pelajar.

Enterprise, Jubilee. (2015). Toko Online Dropshipping dengan wordpress. Jakarta : PT Elex Media Komputindo.

Hasan, M.Ali. (2003). Berbagai Macam Transaksi dalam Islam. Jakarta : Raja Grafindo Persada.

Haroen, Nasrun. (2000). Fiqih Muamalah. Jakarta : Gaya Media Pratama.

Haryosanne, Widya Ismadewi. (2013). Tinjauan Hukum Islam Terhadap Akad Jual Beli Sistem Dropshipping (Studi Kasus Di Toko Online Syafa Onshop Website : Www.Facebook.Com/Groups/Syafa.Onshop/). Semarang : Skripsi Fakultas Syari'ah Dan Ekonomi Islam, IAIN Walisongo.

Helianthusonfri, Jeffriy. (2013). Sukses Bisnis Toko Online. Jakarta : Elex Media Komputindo.

Herlini. (2014). Hukum Fiqih jual Beli Dropshipping. http://www.ummionline.com/hukum-fiqih-jual-beli-dropshipping.html. Diakses 19-Juni-2015.

Huda, Mochammd Choirul. (2010). Transaksi Jual Beli Dengan Sistem Online. Surabaya: Skripsi Fakultas syariah, IAIN Sunan Ampel. http://digilib.uinsby.ac.id/

Ibnu, Mas'ud \& Abidin, Zainal. (2007). Fikih Mazhab Syafi'I . Bandung : Pustaka Setia.

Iswidharmanjaya, Derry. (2012). Dropshipping Cara Mudah Bisnis Online. Jakarta: PT Elex Media Komputindo.

Khulwah, Juhrotul. (2013). Tinjauan hukum Islam terhadap jual beli dropship. Skripsi tidak dipublikasikan, Yogyakarat : Fakultas Syariah, UIN sunan kalijaga.

Karim, Adiwarman Azwar. 2012. Sejarah Pemikiran Ekonomi Islam. Jakarta : PT Raja Grafindo.

Kurniawan, Dudi. (2012). Dropshipping Dalam Tinjauan Syari'ah.

Lubis, Suhrawardi K. (2000). Hukum Ekonomi Islam, Jakarta: Sinar Grafika.

Musa, Muhammad Yusuf. (1976). Al-Amwal Wa Nazhariyah Al-'Aqd. Mesir : Dar al-Fikr Al'arabi. 
Muslich, Ahmad wardi. (2010). Fiqih Muamalah. Jakarta : Amza.

Mansooro, Muhammad Tahir. (2009). Kaidah-kaidah fiqh Keuangan dan Transaksi Bisnis. Bogor : Ulil Albab Institute..

Mahmudi. (2013). Analisis dan Perancangan Sistem Penjualan Berbasis Web pada Toko Oncell. Bandar Lampung : Stimik Tektorat .

Malikah, Zumrotul. 2012. Konsep Harga Lelang Dalam Perspektif Islam. Skripsi dipublikasikan, Semarang : Fakultas Syari'ah. IAIN Walisongo.

Nuriasari, Selvia. (2014). Bisnis Online Dalam Perspektif Islam. Metro: Stain Jurai Siwo

Rachmayana ,Vina \& Sandy L, Rinaldy, (2012). Jual Beli Online Menurut Syariat Agama Islam. Makalah Pendidikan Agama Islam, Surabaya : Fakultas Ilmu Sosial, Unesa.

Purkon, Arif. (2014). Bisnis online syariah. Jakarta : Gramedia

Purnomo, Catur Hadi. (2012). Jual Beli Online Tanpa Repot dengan Dropshipping. Jakarta : PT Elek media komputindu.

Sabiq, Sayyid. (2004). Fiqih Sunnah Jilid 4. Jakarta : Pena Pundi Aksara.

Sarwat, Ahmad. (2013). Hukum Menjual Dropshipping apakah Halal?. http://www.rumahfiqih.com/x.php?id=1357202999. Diakses 21-04-2015.

Setiawan, Deny. (2014). Buat Toko Online Sendiri dengan Opencart. Yogyakarta: Andi Offset.

Serfiani, C.Y., Purnomo, D.P \& Hariyani, I. (2013). Bisnis Online dan Transaksi Elektronik. Jakarta : PT. Gramedia Pustaka Utama.

Sudarsono. (1992). Pokok-pokok Hukum Islam. Jakarta: Rineka Cipta,

Sugiyono. (2012). Metode Penelitian Kuantitatif, Kualitatif, dan R\&D. Bandung : ALFABETA

Sulianta, Feli. (2014). Terobosan Penjualan Online Ala Dropshipping ++. Yogyakarta : ANDI

Sulianta, Feli. (2015). Langkah Jitu Jualan Online. Bandung: PT. Publika Edu Media.

Sunarto, Andi. (2009). Seluk Beluk E-Commerce. Yogyakarta : Gara Ilmu.

Supradi, Cecep. (2013). Pertumbuhan e-commerce indonesia tercepat didunia. http://www.marketing.co.id/pertumbuhan-e-commerce-indonesia-tercepat-didunia/. Diakses tanggal 21-Mei-2015.

Tarmizi, Erwandi. (2012). Bisnis Online dalam Tinjauan Syariah. Majalah Pengusaha Muslim, Edisi 01, No. 23.

Tanpa Nama. (2011). Daftar Perusahaan dropship. http//www.indonetwork.co.id/ companies/dropship. Diakses pada tanggal 20 Mei 2015.

Tanpa Nama. (Tanpa Tahun). Peluang Bisnis Online. http://apjii.or.id./2/read/page/ halaman-data/9/statistik html. Diakses tanggal 06 april 2015.

UU No. 8 Tahun 1999 tentang Perlindungan Konsumen.

Komputer, Wahana. (2013). Membangun Usaha Bisnis Dropshipping. Elex Media Komputindo.

Wijaya, Anis. (2004). Hukum Islam Terhadap Praktek Jual Beli Air di Perusahaan Air Minum Kota Semarang. Semarang.

Wulandari, Agustina. (2014). Kaya Raya Menjadi Raja Bisnis Online. Yogykarta: Flashbooks.

Wyndo Mitra \& filed under Berita Ecommerce Indonesia. (2014). http://startupbisnis.com/ data-statistik-mengenai-pertumbuhan-pangsa-pasar-ecommerce-di-indonesia-saat-ini. Diakses tanggal 21 Mei 2015. 